\title{
OPIOID PEPTIDES SELECTIVE FOR MU- AND DELTA-OPIATE RECEP- TORS REDUCE CALCIUM-DEPENDENT ACTION POTENTIAL DURA- TION BY INCREASING POTASSIUM CONDUCTANCE
}

\author{
MARY ANN WERZ and ROBERT L. MACDONALD* \\ Department of Neurology, University of Michigan, Ann Arbor, MI 48109 (U.S.A.)
}

(Received July 19th, 1983; Revised version received September 13th, 1983; Accepted September 15th, 1983)

Key words: opioid peptide actions - opioid receptors - calcium action potential - potassium conductance - sensory ganglion neuron

We suggest that both mu- and delta-opiate receptors on dorsal root ganglion neuron somata are coupled to voltage- and/or calcium-dependent potassium channels since opioid peptide decreases of calciumdependent action potential duration were: (1) not associated with a change of resting membrane potential or conductance; (2) accompanied by an increase in action potential after-hyperpolarization, and (3) blocked by intracellular injection of the potassium channel blocker cesium [18]. In contrast, norepinephrine [4] and cadmium [9], which have been reported to act on voltage-dependent calcium rather than potassium channels, shortened action potential duration and decreased afterhyperpolarization amplitude, an action not blocked by intracellular iontophoresis of cesium.

Opiates decrease the duration of somatic calcium-dependent action potentials of mouse $[19,20]$ and chick [14] dorsal root ganglion (DRG) neurons grown in primary dissociated cell culture. This opiate action is antagonized by naloxone. It is likely, therefore, that opiate receptors on the somata of these DRG neurons are functionally similar to opiate receptors on primary afferent terminals $[5,6,10]$ where a decrease in calcium entry would correlate with a decrease of neurotransmitter release $[7,12,14]$. We have recently reported that opioid peptides selective for both mu- and delta-opiate receptors decrease the duration of DRG neuron somatic calcium-dependent action potentials [20]. At present, the identity of the ion channels coupled to mu- and delta-opiate receptors is uncertain. It has been suggested that opiates decrezse a voltage-dependent calcium conductance [14] or produce a membrane hyperpolarication by increasing a potassium conductance [15, 18, 21]. We now suggest that in mouse DRG neurons in cell culture both mu- and delta-

\footnotetext{
* Author for correspondence at: Neuroscience Laboratory Bldg., 1103 East Huron Street, Ann Arbor, MI 48109, U.S.A.
} 
receptors are coupled to voltage- and/or calcium-dependent potassium channels.

Preparation of mouse spinal cord and DRG neuron co-cultures and electrophysiological techniques were as previously described [16]. Recording medium was a Tris- $\mathrm{HCl}$-buffered ( $\mathrm{pH} 7.2-7.4)$ balanced saline (320 mOsm) containing (in $\mathrm{mM}$ ): $\mathrm{NaCl}, 137.0 ; \mathrm{KCl}, 5.3 ; \mathrm{MgCl}_{2}, 0.8 ; \mathrm{CaCl}_{2}, 5.0$; Tris-base, 13.0; glucose, 5.6, and tetraethylammonium-chloride (TEA), 5.0. TEA, a potassium channel blocker, augmented the calcium component of action potentials. DRG neurons were impaled with either $4 \mathrm{M}$ potassium acetate (KAc)- or $4 \mathrm{M}$ cesium acetate (CsAc)-filled micropipettes (20-40 M ) and somatic calcium-dependent action potentials were evoked by brief (100-500 $\mu \mathrm{sec})$ depolarizing current pulses at a frequency of 4 per min. Morphiceptin (Peninsula), leucine-enkephalin (Calbiochem), norepinephrine (Sigma), or cadmium (Sigma) were applied to single neurons by pressure ejection $(0.5-2.0$ psi with $1 \mathrm{psi}=6.76 \mathrm{kPa})$ from micropipettes with tip diameters of 2-5 $\mu \mathrm{m}$. Application was for $1 \mathrm{sec}$ delivered $4 \mathrm{sec}$ prior to evoking an action potential.

During recording with KAc-filled micropipettes, action potentials were evoked from resting membrane potential $(-45$ to $-70 \mathrm{mV})$ and generally had durations between 7 and $20 \mathrm{msec}$. Following determination of the effects of the opioid peptides, norepinephrine or cadmium on calcium-dependent action potential duration, the KAc-filled recording micropipette was gently withdrawn from the neuron. The neuron was then reimpaled with a recording micropipette containing CsAc and action potentials were evoked. Initially following neuronal impalement with a CsAcfilled micropipette, resting membrane potential, action potential duration and action potential after-hyperpolarization corresponded to those observed during KAr recordings. Over the next $1-15 \mathrm{~min}$, membrane potential declined to 0 to $-20 \mathrm{mV}$, action potential duration increased to $100-1500 \mathrm{msec}$, and the afterhyperpolarization was abolished, consistent with substantial blockade of potassium conductance by intracellular cesium. Holding current was applied to maintain baseline membrane potential at about $-60 \mathrm{mV}$. The action of the opioid peptides, norepinephrine and cadmium was then reassessed on the prolonged calciumdependent action potentials obtained following intracellular cesium injection. A more detailed description of methods used can be found in Werz and Macdonald [21].

During intracellular recording with KAc-filled micropipettes, the opioid peptides (Fig. $1 A_{1}$ ), norepinephrine (Fig. $1 B_{1}$ ) and cadmium (Fig. $1 C_{1}$ ) decreased the duration of somatic calcium-dependent action potentials. As previously reported, the opioid peptides affected only a portion of DRG neurons. Of 90 DRG neurons tested, only 13 responded to 5-10 $\mu \mathrm{M}$ leucine-enkephalin or 5-10 $\mu \mathrm{M}$ morphiceptin with a decrease of somatic calcium-dependent action potential duration of at least $25 \%$. Norepinephrine at $100 \mu \mathrm{M}$ decreased calcium-dependent action potential duration in 6 of 6 neurons by $11-35 \%$, with a mean reduction of $20 \%$. Cadmium at $100-500 \mu \mathrm{M}$ abolished the calcium-dependent component in 11 of 11 neurons leaving an action potential of $2 \mathrm{msec}$ duration which was sodium-dependent. 


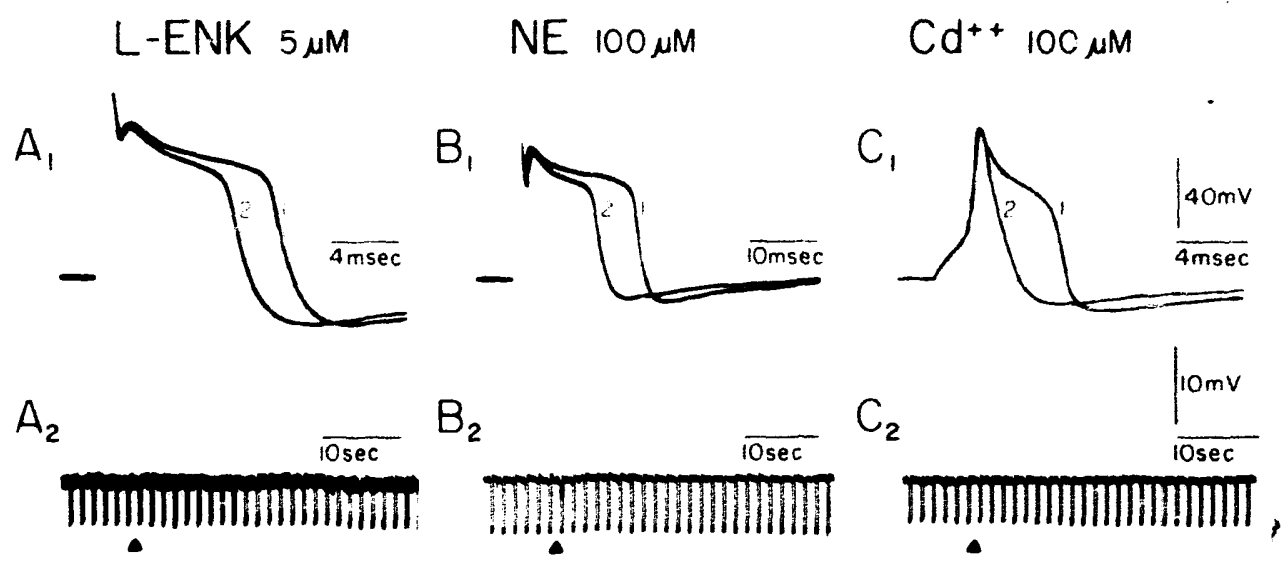

Fig. 1. Leucine-enkephalin (L-ENK) $\left(A_{1}, A_{2}\right)$, norepinephrine $(N E)\left(B_{1}, B_{2}\right)$, and cadmium $\left(C d^{++}\right)\left(C_{1}\right.$, $C_{2}$ ) decreased DRG neuron somatic calcium-dependent action potential duration without affecting resting membrane potential or conductance. Intracellular recordings from 3 different neurons (A, B and C) obtained using KAc-filled micropipettes. $A_{1}, B_{1}$ and $C_{1}$ : action potentials were evoked from neurons bathed in medium containing $5 \mathrm{mM}$ TEA and therefore had durations of 5-20 msec. Approximately 2 msec was dependent upon sodium with the remaining broad plateau dependent upon calcium. Data in this and subsequent figures are superimposed action potentials evoked prior to (1) and subsequent to (2) L-ENK, NE, or $\mathrm{Cd}^{++}$application. $\mathrm{A}_{2}, \mathrm{~B}_{2}$ and $\mathrm{C}_{2}$ : depolarizing stimuli to evoke action potentials were discontinued. L-ENK $\left(\mathrm{A}_{2}\right), \mathrm{NE}\left(\mathrm{B}_{2}\right)$ and $\mathrm{Cd}^{+{ }^{+}}\left(\mathrm{C}_{2}\right)$ applied for $1 \mathrm{sec}$ at triangle did not affect membrane potential or the voltage responses to injection of small, hyperpolarizing constant current pulses.

Decreases of DRG neuron somatic calcium-dependent action polentials by the

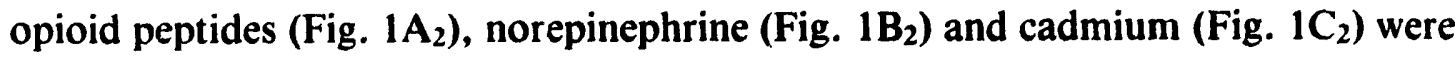
not associated with a change of resting membrane potential or conductance.

Opiate action differed from that of norepinephrine and the calcium channel blocker cadmium in two ways. Firstly, the peak amplitude of action potential afterhyperpolarization was increased $1-7 \mathrm{mV}$ (mean $2.4 \mathrm{mV}$ ) by opioid peptides ( 9 of 12 neurons) (Fig. 2A) but decreased 1-2.5 mV (mean $1.7 \mathrm{mV}$ ) by norepinephrine (6 of 6 neurons) (Fig. 2B) and $1-10 \mathrm{mV}$ (mean $3.3 \mathrm{mV}$ ) by cadmium ( 9 of 9 neurons) (Fig. $2 C)$. The opioid peptides did not affect the amplitude of the after-hyperpolarization in 2 neurons and decreased it slightly in one. Secondly, in DRG neurons that had responded to the opioid peptides during recording with KAc-filled micropipettes, the response was blocked by intracellular cesium (Fig. 3A, B) (10 of 10 neurons). Opioid peptide responses were blocked by intracellular cesium in neurons that responded to both morphiceptin and leucine-enkephalin (Fig. 3A) (3 of 3), presumably mu-receptor-mediated responses, and in neurons that responded to leucine-enkephalin but not morphiceptin (3 of 3) (Fig. 3B), presumably deltareceptor-mediated responses. In contrast, DRG neurons $(n=6)$ that responded to norepinephrine with a decrease of action potential duration of 11-35\% (mean reduction $20 \%$ ) during recording with KAc-filled micropipettes responded with a reduction of $25-66 \%$ (mean reduction $37 \%$ ) during subsequent recording with CsAc-filled micropipettes (Fig. 3C). Cadmium abolished the calcium-dependent 
A L-ENK $5 \mu \mathrm{m} \quad$ B NE $100 \mu \mathrm{m} \quad$ C $\mathrm{Cd}^{*+} 500 \mu \mathrm{m}$
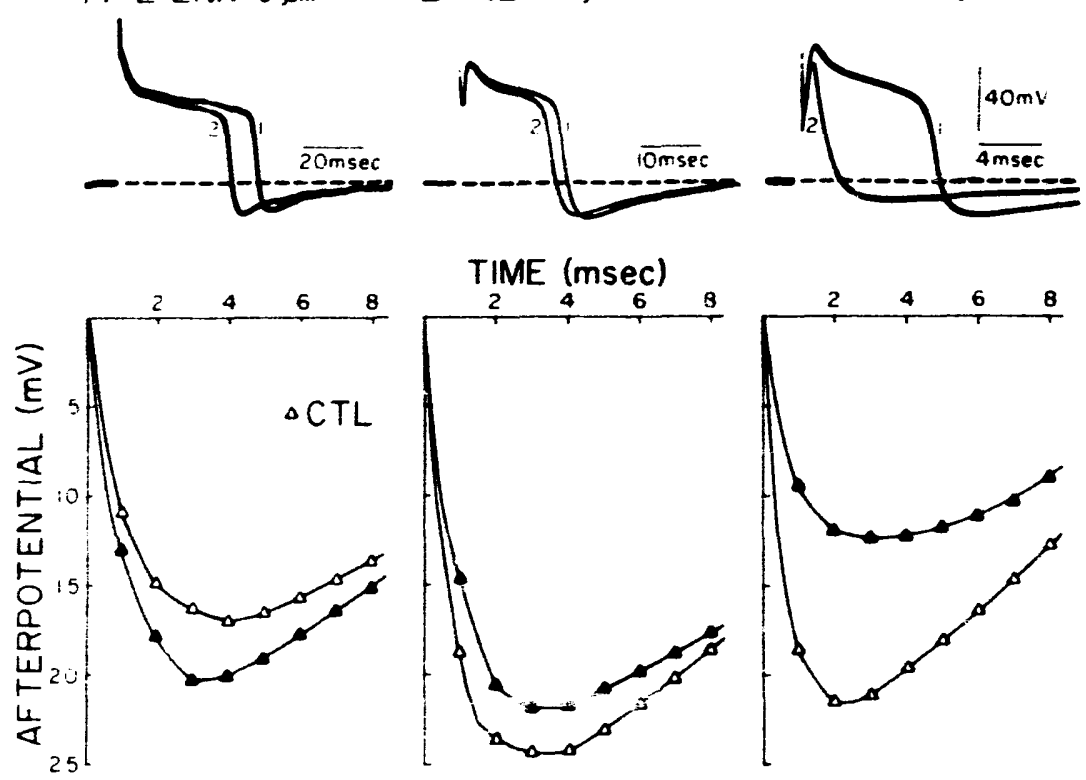

Fig. 2. Opioid peptides increased while norepinephrine and cadmium decreased action potential afterhyperpolarization. Upper panel: effect of L-ENK (A), NE (B), and $\mathrm{Cd}^{++}(C)$ on action potential duration and after-hyperpolarization. Broken line indicates resting membrane potential. Lower panel: afterhyperpolarization amplitudes of action potentials shown in upper panel are plotted as a function of time. Measurement of after-hyperpolarizations was begun where the repolarizing limb of the action potential intersected resting membrane potential. In each case, control is designated by open triangles and opioid peptide, norepinephrine, or cadmium treated by closed triangles.

component of action potentials during recording with either KAc- or CsAc-filled recording micropipettes $(n=5)$ (Fig. $3 C)$.

The opioid peptides leucine-enkephalin and morphiceptin, norepinephrine and cadmium decreased the duration of the calcium component of DRG neuron somatic calcium-dependent action potentials without affecting resting membrane potential or conductance, suggestive of an action to decrease voltage-dependent calcium conductance or to increase voltage- and/or calcium-dependent potassium conductance. Norepinephrine and cadmium appear to act by the first mechanism, a decrease of voltage-dependent calcium conductance, as shown by decreased calcium-dependent action potential duration under conditions of substantial potassium channel blockade and by the reduced amplitude of action potential after-hyperpolarizations. A decrease of calcium entry would be expected to produce less activation of calciumactivated potassium conductance. This interpretation is supported by voltage clamp studies demonstrating that cadmium abolished the early calcium inward current evoked by depolarizing voltage steps and also reduced the magnitude of the late outward current [14]. Our results that norepinephrine decreased a voltage-dependent calcium conductance are consistent with the findings of Dunlap and Fischbach [5].

In contrast, opioid peptide effects on action potential duration were frequently associated with an increase in amplitude of after-hyperpolarization and were block- 


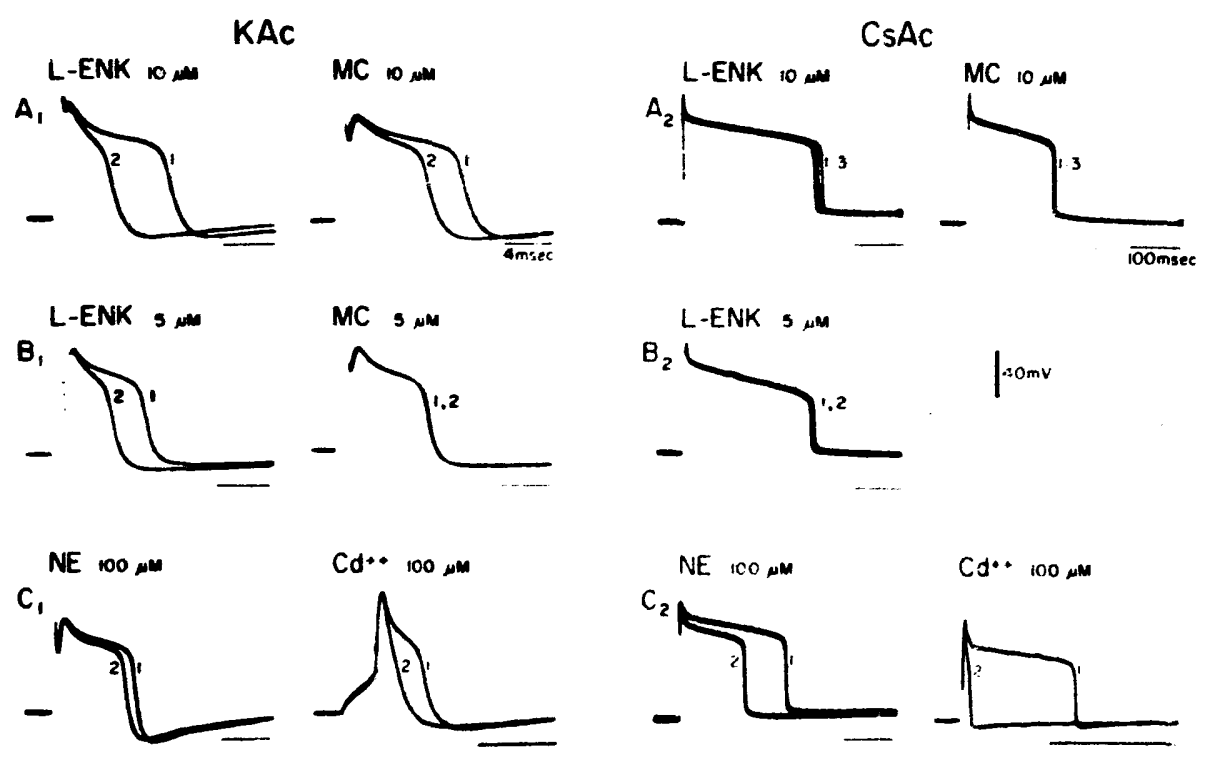

Fig. 3. Intracellular injection of cesium blocked neuronal responses to L-ENK anci morphiceptin (MC) but not to $\mathrm{NE}$ or $\mathrm{Cd}^{++}$. Opioid peptides, $\mathrm{NE}$ and cadmium were tested on somatic calcium-dependent action potentials during recording with a KAc-filled micropipette and again following reimpalment of the neuron with a CsAc-filled micropipette. A and B: a DRG neuron that responded well to L-ENK and MC $\left(A_{1}\right)$, presumably a neuron with mu-receptors [20], and a neuron that responded to L-ENK but not MC $\left(B_{1}\right)$, presumably a neuron with predominantly delta-receptors, during recording with KAc-filled micropipettes. Subsequent reimpalement of the neurons with a CsAc-filled micropipette and intracellular injection of cesium blocked the response to the opioid peptides in both cases $\left(\mathbf{A}_{2}, \mathbf{B}_{2}\right)$. Two neurons that responded to $\mathrm{NE}$ and $\mathrm{Cd}^{++}$during recording with $\mathrm{KAc}$-filled micropipettes $\left(\mathrm{C}_{1}\right)$ continued to show large decreases of action potential duration during subsequent recording with CsAc-filled micropipettes $\left(C_{2}\right)$. Calibrations represent $4 \mathrm{msec}\left(A_{1}, B_{1}, C_{1}\right)$ or $100 \operatorname{msec}\left(A_{2}, B_{2}\right.$ and $\left.C_{2}\right)$.

ed by intracellular cesium, suggesting that opiates act by increasing a potassium conductance. Our conclusion is in conflict with the finding of Mudge et al. [14] who suggested that enkephalins decrease a voltage-dependent calcium conductance. However, opiates have been reported to act on potassium conductances in several systems: a potassium conductance present at resting membrane potential $[15,22]$ as well as a potassium conductance activated by calcium [18]. We have not observed an opiate action to increase a potassium conductance at resting membrane potential, consistent with an action on one of several neuronal voltage- or calcium-dependent potassium conductances $[1,2,11]$. Further work wili be necessary to define which potassium conductance is acted upon by opiates in primary sensory neurons and to determine if mu- and delta-receptors are coupled to the same or different potassium channels.

The authors thank Ms. Michaela Weeks for secretarial assistance. M.A.W. was supported by NIDA-DA 5244. R.L.M. was supported in part by NIH Research Career Development Award NS 00480. The research was supported by National Science Foundation Grant BNS 8118762. 
1 Adams, P.R., Voltage-dependent conductances of vertebrate neurones, Trends NeuroSci., 5 (1982) 116-119.

2 Adams, P.R., Constanti, A., Brown, D.A. and Clark, R.B., Intracellular $\mathrm{Ca}^{2+}$ activates a fast voltage-sensitive $K^{+}$current in vertebrate sympathetic neurones, Nature (Lond.) 296 (1982) 746-749.

3 Chang, K.-J., Killian, A., Hazum, E. and Cuatrecasas, P., Morphiceptin (NH4-Tyr-Pro-Phe-Pro$\mathrm{CONH}_{2}$ ): a potent and specific agonist for morphine $(\mu)$ receptors, Science, 212 (1981) 75-77.

4 Dunlap, K. and Fischbach, G.D., Neurotransmitters decrease the calcium conductance activated by depolarization of embryonic chick sensory neurones, J. Physiol. (Lond.) 317 (1981) 519-535.

5 Fields, H.L., Emson, P.C., Leight, B.K., Gilbert, R.F.T. and Iversen, L.L., Multiple opiate receptor sites on $1^{\circ}$ afferent fibers, Nature (Lond.), 284 (1980) 351-353.

6 Hiller, J.M., Siinon, E.J., Crain, S.M. and Peterson, E.R., Opiate receptors in cultures of fetal mouse dorsal root ganglia (DRG) and spinal cord: predominance in DRG neurites, Brain Res., 145 (1978) 396-400.

7 Jessell, T.M. and Iversen, L.L., Opiate analgesics inhibit substance $P$ release from rat trigeminal nucleus, Nature (Lond.), 268 (1977) 549-551.

8 Kosterlitz, H.W., Lord, J.A.H., Paterson, S.J. and Waterfield, A.A., Effects of changes in the structure of enkephalins and of narcotic analgesic drugs on their interactions with $\mu$-and $\delta$-receptors, Brit. J. Pharmacol., 68 (1980) 333-342.

9 Kostyuk, P.G. and Krishtal, O.A., Separation of sodium and calcium currents in the somatic membrane of molusc neurones, J. Physiol. (Lond.), 270 (1977) 545-568.

10 Lamotte, C., Pert, C.B. and Snyder, S.H., Opiate receptor binding in primate spinal cord: distribution and clianges after dorsal root section. Brain Res., 112 (1976) 407-412.

11 Macdermott, A.B. and Weight, F.F., Action potential repolarization may involve a transient, $\mathrm{Ca}^{2+}$-sensitive outward current in a vertebrate neurone. Nature (Lond.) 300 (1982) 185-188.

12 Macdonald, R.L. and Nelson, P.G., Specific opiate-induced depression of transmitter release fron dorsal root ganglion cells in culture, Science, 199 (1978) 1449-1451.

13 Macdonald, R.L. and Werz. M.A., Barbiturates decrease voltage-dependent calcium conductance of mouse neurons in dissociated cell culture, Soc. Neurosci. Abstr., 8 (1982) 568.

14 Mudge, A.W. Leeman, S.E. and Fischbach, G.D., Enkephalin inhibits release of substance $P$ from sensory neurons in culture and decreases action potential duration, Proc. nat. Acad. Sci. USA, 76 (1979) 526-530.

15 Pepper, C.M. and Henderson, G., Opiates and opioid peptides hyperpolarize locus coeruleus neurons in vitro, Science, 209 (1980) 394-396.

16 Ransom, B.R., Neale, E., Henkart, M., Bullock, P.N. and Nelson, P.G., Mouse spinal cord in cell culture. I. Morphology and intrinsic neuronal electrophysiologic properties, J. Neurophysiol., 40 (1977) 1132-1150.

17 Tillotson, D. and Horn, R., Inactivation without facilitation of calcium conductance in caesiumloaded neurones of Aplysia, Nature (Lond.), 273 (1978) 312-314.

18 Tokimasa, T., Morita, K. and North, R.A., Opiates and clonidine prolong calcium-dependent afterhyperpolarizations, Nature (Lond.) 294 (1981) 162-163.

19 Werz, M.A. and Macdonald, R.L., Opioid peptides decrease calcium-dependent action potential duration of mouse dorsal root ganglion neurons in cell culture, Brain Res., 239 (1982) 315-321.

20 Werz, M.A. and Macdonald, R.L., Heterogeneous sensitivity of cultured dorsal root ganglion neurones to opioid peptides selective for $\mu$ - and $\delta$-opiate receptor, Nature (Lond.), 299 (1982) 730-733.

21 Werz, M.A. and Macdonald, R.L., Opioid peptides with differential affinity for mu- and deltareceptors decrease sensory neuron calcium-dependent action potentials, J. Pharmacol. exp. Ther., 227 (1983) 394-402.

22 Williams, J.T., Egan, T.M. and North, R.A., Enkephalin opens potassium channels on mammalian central neurones, Nature (Lond.), 299 (1982) 74-77. 